\title{
Modelling Beef and Dairy Sectors' Productivities and their Effects on Land Use Change in Brazil ${ }^{1,2}$
}

\author{
Leila Harfuch ${ }^{3}$, André Meloni Nassar ${ }^{4}$, Wilson Milani Zambianco ${ }^{5}$ and \\ Angelo Costa Gurgel ${ }^{6}$
}

\begin{abstract}
This paper aims to develop new methodology for the Brazilian beef and dairy sectors incorporating different levels of productivities in the Brazilian Land Use Model (BLUM), analyzing land use dynamics. Several datasets combinations were used and supply and demand equations were re-estimated. Historical database developed in this paper shows that the livestock sector increased productivity levels per hectare (in both beef and dairy sectors), being an important land releaser for other agricultural uses. Even in frontier regions, the occupation process was followed by productivity increase. When technologies were implemented in BLUM, results show that there were significant differences on land use in 2030, reducing land for pasture compared to BLUM previous version. In this sense, the study concludes that: using average productivity levels on modeling can overestimate pastureland; migration between technologies (lower to higher levels) will continue in the future; and, finally, market and agents' behavior changes might be incorporated in land use economic models, so they can reproduce empirical evidences.
\end{abstract}

Key-words: Land use; Beef and dairy; Production technologies; Economic modeling.

Resumo: Este artigo tem como objetivo desenvolver uma metodologia para a pecuária de corte e de leite incorporando diferentes níveis de produtividade no Modelo de Uso da Terra para a Agricultura Brasileira (BLUM) e avaliar a dinâmica do uso da terra. Combinações

1. Data de submissão: 9 de fevereiro de 2015. Data de aceite: 9 de março de 2016.

2. Os autores agradecem o apoio da Fapesp e as contribuições analíticas de Maurício Palma Nogueira (sócio-coordenador da divisão pecuária da Agroconsult. Florianópolis-SC, Brasil).

3. Pesquisadora Sênior da Agroicone. São Paulo (SP), Brasil. E-mail: leila@agroicone.com.br

4. Diretor Geral da Agroicone até março de 2015 (São Paulo-SP, Brasil) e Secretário de Política Agrícola do Ministério da Agricultura, Pecuária e Abastecimento (Brasília-DF, Brasil). E-mail: amnassar@agroicone.com.br

5. Pesquisador da Agroicone (até agosto de 2015), São Paulo-SP, Brasil. E-mail: zambianco@agroicone.com.br

6. Professor da Escola de Economia de São Paulo, da Fundação Getúlio Vargas. São Paulo-SP, Brasil. E-mail: angelo_gurgel@yahoo.com.br. 
de fontes de dados foram utilizadas e equações de oferta e demanda foram reestimadas. Com base no levantamento de dados, pode-se afirmar que a pecuária brasileira aumentou a produtividade por hectare (de corte e de leite), sendo um importante "doador" de área produtiva para outros usos agrícolas. Mesmo em regiões de fronteira agrícola, o processo de ocupação foi seguido de aumento de produtividade. Ao implementar as tecnologias no BLUM, os resultados mostram que houve diferenças no uso da terra projetado para 2030, com menor área alocada para pecuária em relação à versão anterior do BLUM. Assim, pode-se concluir que: ao utilizar apenas a produtividade média da pecuária, o modelo tende a superestimar a área de pastagens; a migração entre tecnologias (de mais baixas para mais elevadas) tende a continuar no futuro; e, por fim, mudanças de comportamento do mercado e dos agentes econômicos devem ser incorporados nos modelos econômicos de uso da terra para que possam reproduzir evidências empíricas.

Palavras-chaves: Uso da terra; Pecuária; Tecnologias de produção; Modelagem econômica.

JEL Classification: Q13, Q15, Q16.

\section{Introduction}

Brazil has an important role on beef supply, both for domestic consumption and global exports. Since 2005, the country has been the second largest beef producer in the World, after the United States, and production growth rate increased rapidly. According to USDA (2014), in 1996, beef production was 6 million tons, reaching 9.7 million tons in 2005 and almost a million more in 2013. Exports is an important driver to the sector expansion. While in 1996 exports represented less than 100 thousand tons, in 2005 it achieved 1.9 million tons, representing $25 \%$ of global trade and became the world largest exporter.

Since most of beef and dairy production come from pasture based systems in Brazil, pasture occupies a large amount of land, around 170 million hectares (LAPIG, 2014). Due to its extension and the possibility to increase the production per hectare, pasture has an important role on land use dynamics with a large potential to release area to crops (COHN et al., 2014).

According to Martha Jr., Alves and Contini (2011), between 1950 and 2006 productivity yields explained $79 \%$ of beef and dairy production increase in Brazil and it was responsible for saving 525 million ha on land use for pastures. Same authors affirm that between 1996 and 2006, livestock activity started a modernization process, increasing yields by $6.6 \%$ per year. Other studies suggest that the productivity of pasture increased substantially during the past decades and technologically more advanced and more efficient livestock production systems will be used in the future, mainly driven by competition for land among crops and pastures and environmental restrictions for land expansion (NEPSTAD et al., 2014; GIBBS et al., 2015; STRASSBURG et al., 2014).

Although livestock sector globally is responsible for two thirds of the land used for agriculture, representation of this sector in most of economic models should be improved (STEHFEST et al., 2013). Several land use models do not capture pasture intensification dynamics or, if so, do not consider empirical evidences and observed historical data to calibrate the models. However, lack of database also challenge researchers, and that is why developing database for the livestock sector is key for any land use change analysis for Brazil.

For the exposed reasons, this paper has two main objectives: understand Brazilian beef and dairy sectors dynamics (on land use) based on database analysis and development; and build a new module (improving land use dynamics methodology) in BLUM - Brazilian Land Use Model in order to better capture land use dynamics.

The methodology used was based on land use, supply and demand assessment for beef and 
dairy sectors, as developed in the Brazilian Land Use Model - BLUM. The following sections will provide detailed methods and methodologies used, step by step ${ }^{7}$.

\section{Database improvements for beef sector: methodology and results}

Due to its complexity, database for the Brazilian beef sector need to be adapted and estimated considering different available sources. The reason behind this is that the main public source for the agricultural sector, IBGE, presents an inconsistent number for slaughtered animals compared to estimated beef consumption, exports and, consequently, production.

This issue also challenges agriculture and land use modelers, which understanding the sector and how it is translated into database and modeling are key to reproduce empirical evidence. This paper will show both approaches: estimating database and modeling the beef sector and land use.

The following logic was implemented in order to improve the beef sector historical database in BLUM (described in the next subsections): (i) estimate pasture area database; (ii) estimate the number of slaughtered animals and carcass weight for Brazil and BLUM regions

7. It is important to mention that the database and methodology developed in this paper are unique, adapted for the BLUM model. The productivity database developed was simplified in order to represent the average production per hectare in each productivity level. Although this simplification is necessary for the modeling, technological profile for beef and dairy sectors was not considered on land use models for Brazil, making this paper an important advance for the literature. The authors are aware that there are several productive systems on beef and dairy sectors, such as croplivestock-forest integration, feedlots productive systems, sustainable intensification using better agricultural practices among others, but the main objective is to have production per hectare, independently of each specific productive system. Also, there is no detailed database available to ideintify each productive system in different Brazilian regions (such as the amount of land allocated in each activity, production of beef and other products per ha, productivity per ha, etc.), making impossible to incorporate detailed information into the model. considering formal and informal slaughter (beef sector); (iii) estimate cattle herd per category for Brazil and BLUM regions (beef and dairy sectors); (iv) estimate technological profile for Brazil and BLUM regions considering zoo technical indexes and calculated productivities (beef and dairy sectors); (v) estimate costs of production for different technology level and returns per hectare (beef and dairy sectors).

\subsection{Pasture database}

Pasture data in Brazil is only officially published by the Agricultural Census, which is the most detailed land use database in Brazil. However, although the Agricultural Census is available for a good number of years (1970, 1975, 1980, 1985, 1996 and 2006), there is no time series and up-to-date Agricultural Census. In addition, pasture data from 2006 has been highly criticized, due to the difficulties on collecting the information in areas that are not easily accessible, especially in the Amazon states. Time series for pasture data is available only for Sao Paulo state from the Instituto de Economia Agrícola (IEA).

In order to have land allocation for pastures projected by BLUM, this study used a two-step approach to develop a database for pastures. First, pasture area was defined for two years: 1996 and 2006. Second, a time series was developed from 1997 to 2005, and extended from 2007 to 2012, in order to cover the whole period of time-series historical data in the model. Although BLUM model needs data for its six regions ${ }^{8}$, state level data were used for 1996 and 2006. Using the results generated by Gouvello et al. (2010), pasture area for 2006 was obtained

8. BLUM considered Brazil divided into six regions: South (states of Parana, Rio Grande do Sul e Santa Catarina); Southeast (states of São Paulo, Minas Gerais, Rio de Janeiro and Espírito Santo); Center-West Cerrado (states of Mato Grosso do Sul, Goiás, Distrito Federal and part of Mato Grosso state into Cerrado biome); North Amazon (part of Mato Grosso state into Amazon biome, Rondônia, Acre, Amazonas, Pará, Amapá and Roraima); Northeast Coast (states of Ceará, Rio Grande do Norte, Paraíba, Alagoas, Pernambuco and Sergipe) and Northeast Cerrado (states of Maranhão, Piauí, Tocantins and Bahia). 
using satellite images for almost all Brazilian municipalities (excluding the ones located on Pantanal, Caatinga and Pampa biomes). Considering satellite images and Agricultural Census for 2006, this research analyzed carefully both database and considered some criteria to have final pasture area for the year 2006. Also, considering the limitations on Agricultural Census database, some corrections were applied on 1996 data for some specific cases.

All the assumptions and criteria for pasture area in 1996 and 2006 were made considering each case, state by state. Basically, the most important assumption was that total land used for agriculture (considering all crops and pasture) could not decrease considering the 10 year length, 1996 and 2006. In the case of the Amazon region, 1996 pasture data was recalculated based on 2006 satellite images discounting the deforestation rate year by year for some states (like Acre, Amazonas, Para and Rondonia). In the case of Minas Gerais state, data from satellite images for 2006 and 1996 was corrected considering that pasture areas located in areas with high slopes were not captured by Agricultural Census. So, it was used Census database for 1996 plus this pasture area in higher slopes captured by satellite images in 2006. For the state of Sao Paulo, IEA pasture areas for 1996 and 2006 were used.

There are some points to be clear in the CenterWest Cerrado region. For the state of Mato Grosso do Sul was used Agricultural Census 1996 and 2006 pasture data for the municipalities located on all biomes (Atlantic Forest, Cerrado and Pantanal). In the case of the state of Mato Grosso, which is in both Center-West Cerrado and North Amazon regions, was used pasture areas data from the Agricultural Census for 1996 and 2006. To breakdown the state into the two regions, it was considered the municipalities in each biome, considering that for the municipalities located on both biomes was used $50 \%$ of pasture areas in each region, methodology also used for all other crops areas in BLUM model. For the state of Goiás and Distrito Federal was used the Agricultural Census for both years. For all other regions (South, Southeast except the state of Sao Paulo and Minas Gerais, Northeast Cerrado) pasture areas were from Agricultural Census for both years 1996 and 2006.

The second step is to create a time series for the years that there is not available information for pasture areas. Two set of data were used: 1) deforestation rate; 2) cattle herd and lagged pasture area. For the Amazon region was used the deforestation rate discounting the expansion of crops areas year buy year, from 1997 to 2005 . For 2007 and 2008 the deforestation rate was add on 2006 pasture area. For the other regions, since the state of Sao Paulo has a time series, it was estimated a regression on pasture area as a function of lagged pasture area and cattle herd. For all the regions was used the coefficients estimated to construct the time series, considering some adjustments, except for the Amazon as explained above.

Table 1. Pasture area in BLUM regions for 1996 and 2006 (hectares)

\begin{tabular}{lcc}
\hline & $\mathbf{1 9 9 6}$ & $\mathbf{2 0 0 6}$ \\
\hline South & $20,696,549$ & $16,109,752$ \\
Southeast & $31,287,315$ & $28,526,107$ \\
Center-West Cerrado & $55,058,330$ & $49,503,929$ \\
North Amazon & $33,944,605$ & $45,472,201$ \\
Northeast Coast & $9,877,573$ & $10,885,014$ \\
Northeast Cerrado & $33,276,922$ & $32,778,453$ \\
Brazil & $184,141,294$ & $183,275,457$ \\
\hline
\end{tabular}

Source: research results. 


\subsection{Slaughtered animals and carcass weight database}

Since 1997, IBGE (2014a) publishes database on a quarterly research for slaughtered animals, detailing the type of sanitary inspection and by category of cattle (cows, steers, heifers and calves). The regional division on inspection also restricts the regional commercialization, which means that county sanitary inspection restricts to the county the production and final consumption of the animal product. However, IBGE (2014a) database is insufficient to explain the total supply of beef, because it does not account total slaughtered cattle. There is a large "informal" production of beef in Brazil, not captured in the published database. This is evident when we compare for a historical period the difference on the number of slaughtered animals with the production of bovine leather, which should be one to one relationship (Figure 1).
Specialists on the sector has using leather database to determine the adjustments on slaughtered animals and estimate beef production. This approach was combined with the slaughtered animals by category and by inspection type, since bovine leather is still lower than total estimated slaughtered bovines (due to quality of bovine skin and losses) and a new database was estimated for BLUM regions and Brazil, as shown in Figure 2.

Both Figures 1 and 2 show that the share of informal slaughter is reducing overtime, due to changes on the sector structure (concentration of industries) and command and control policies.

For slaughtered weight (carcass weight equivalent) was used IBGE (2014a) database for each category and type of inspection and applied to total estimated slaughter by category in order to calculate beef production in a given year.

Figure 1. Comparing slaughtered animals and units of bovine leather from IBGE database (number of heads)

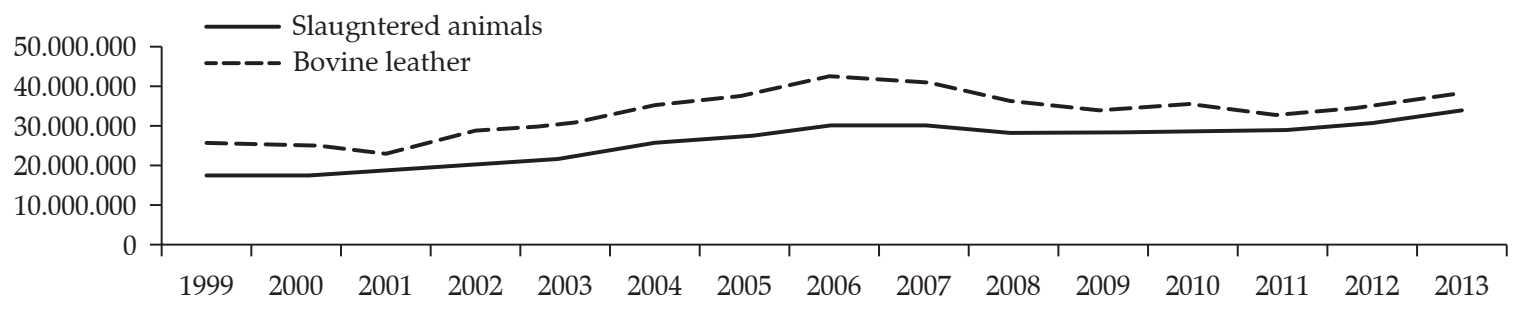

Source: IBGE (2014a), IBGE (2014b).

Figure 2. Total estimated slaughtered for Brazil: complementing IBGE database

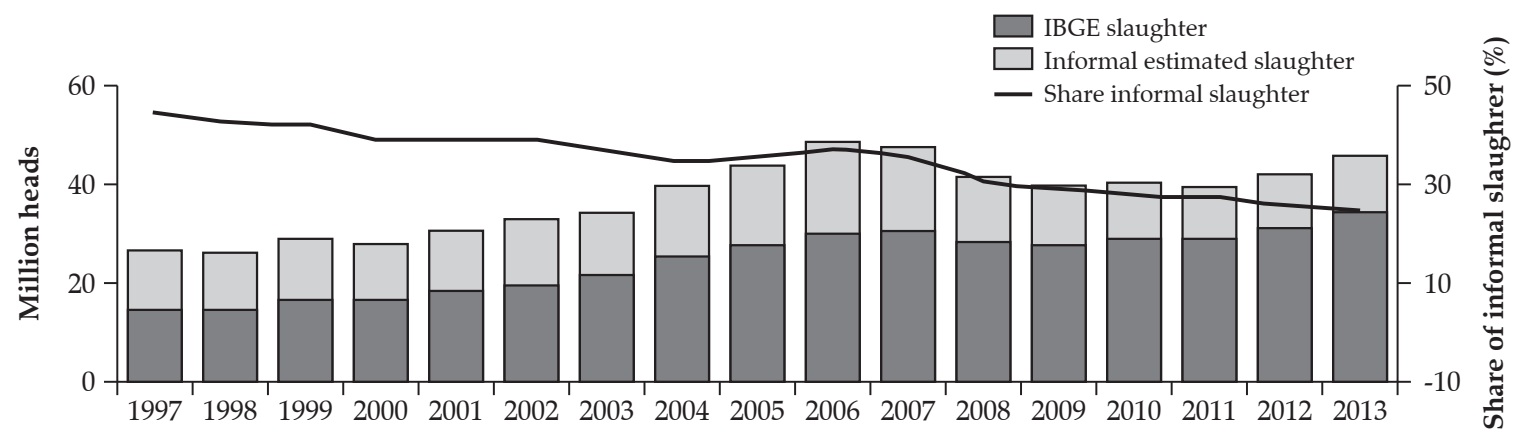

Source: IBGE (2014a), research results. 


\subsection{Estimating cattle herd per category and per region}

For total cattle herd by BLUM region was used IBGE (2014c) database (livestock research by municipality) and this research also provides the number of milking cows, which is used as a sub-category in BLUM (dairy cows is part of total cows shown in Figure 3).

The challenge is to develop a time-series for the different categories of cattle herd by region, since the only available public data is the Agricultural Census (IBGE, 2014d), which has a different number for total cattle herd compared to IBGE (2014c). However, having a starting point in 1996 based on IBGE (2014d) and another for the year 2006, combined with zoo technical indexes and slaughtered animals by category (explained in the previous section), was possible to develop this database considering that the whole Brazil has a complete cycle ${ }^{9}$ system of production. Figure 3 shows the results.

Similar rationale was implemented to estimate the cattle herd by category for the six BLUM regions. Some adjustments were applied to guarantee that the sum of each category by region was the same as estimated for Brazil as whole and also the sum of the categories in each region need to be the same of the total herd of the region estimated using IBGE (2014c).

\subsection{Costs of production and profitability database}

The cost structure is different for each combination of activity and production system and adopted technology. The idea implemented in this paper in order to capture different structures for the beef sector in BLUM is based on yields per hectare applied to a complete cycle productive system (considering 1@ is around $15 \mathrm{~kg}$ of carcass

9. Important to mention that Brazil has several different systems of production for cattle raising. This study considered three productive systems: Cow-Calf System; StockerYearling System and Complete Cycle. weight equivalent - CWE): "Low technology" production up to 3@/hectare/year (up to $45 \mathrm{~kg} / \mathrm{ha} /$ year); "Medium technology" - production from more than3@ and up to 6@/hectare/year (from 45 up to $90 \mathrm{~kg} / \mathrm{ha} /$ year); "Growing technology" more than 6@/hectare/year (more than 90 kg/ha/ year).

The cost structure was developed based on consultancies of cattle ranchers with similar description (based on a complete cycle farm), CNA (2012) and Cepea (2012) available database.

Eleven components of managing costs was considered, including nutritional plan for the cattle, pasture management and fixed costs for the farm: fertilizers; defensives; energy concentrated; protein concentrated; fuel; salt mineral; veterinarian products; immobilized costs; salaries; machineries; administration and reposition. The cost structure is similar for all six regions in BLUM, but the absolute value differs when applied regional prices for each component of cost.

Nutrition and pasture management (fertilizers and defensives use) are the two main important differences on cost structure for the three technologies. For nutrition, supplementary feed (mainly corn and soybean meal) is only considered for growing technology; for fertilizers and defensives are used on medium and growing.

Revenue per hectare for each system was calculated based on the level of productivity per hectare multiplied by the price of kilogram of live cattle. The last one is the same for all technologies, but different in each region. Profitability per hectare is the result of revenue minus cost. Implementing all improvements in BLUM, prices of live cattle per kilogram and productivity per hectare $(\mathrm{kg} / \mathrm{ha})$ are estimated endogenously.

\subsection{Mapping technological profile for the beef sector in Brazil}

Considering the estimated database on pasture area, cattle herd and slaughtered animals per category it is possible to calculate 
Figure 3. Estimated cattle herd by category for Brazil (1,000 heads)

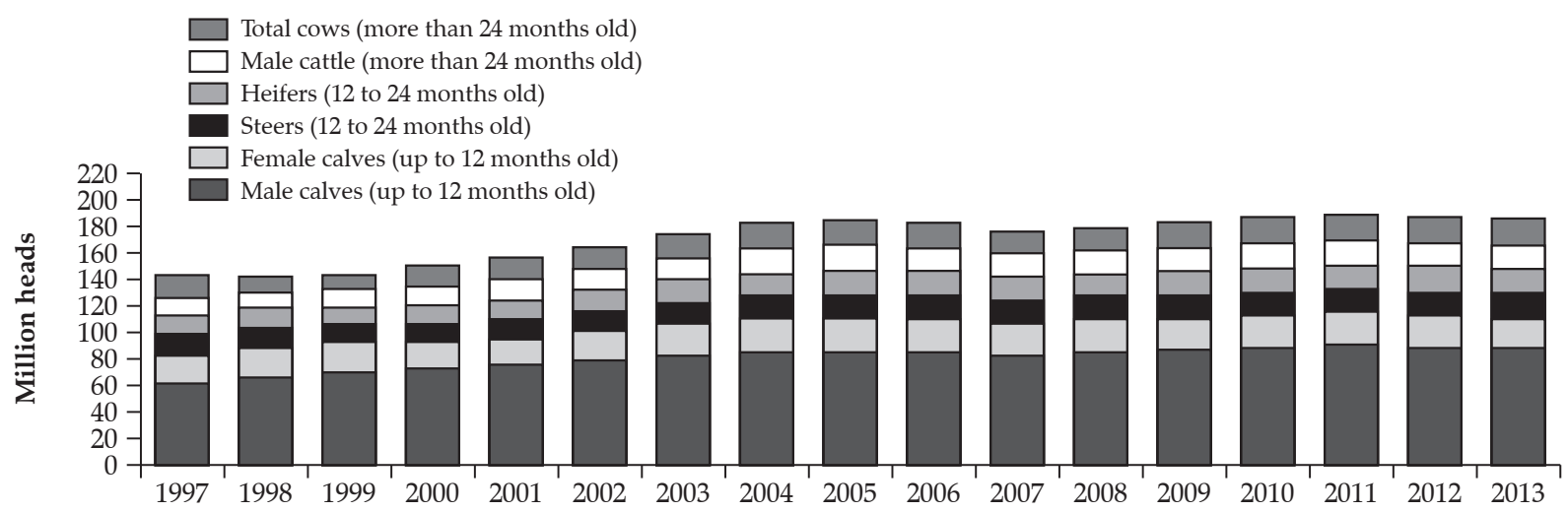

Source: Research results.

Figure 4. Cost structure for Complete Cycle with Low technology
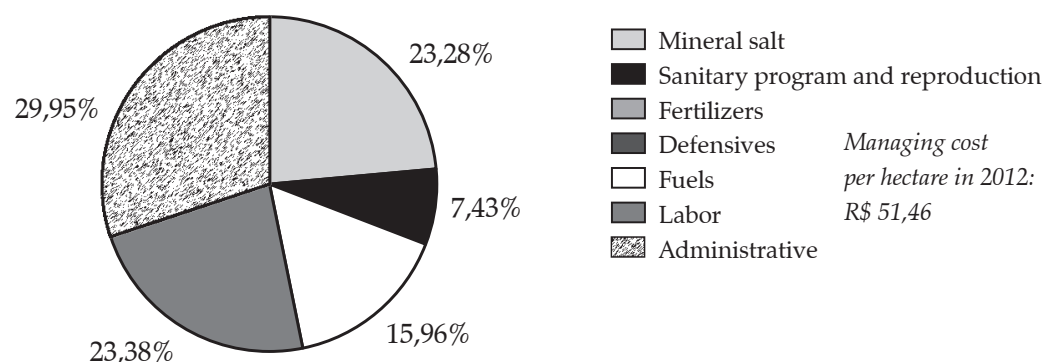

Source: Research results based on Agroconsult database.

Figure 5. Cost structure for Complete Cycle with Medium technology
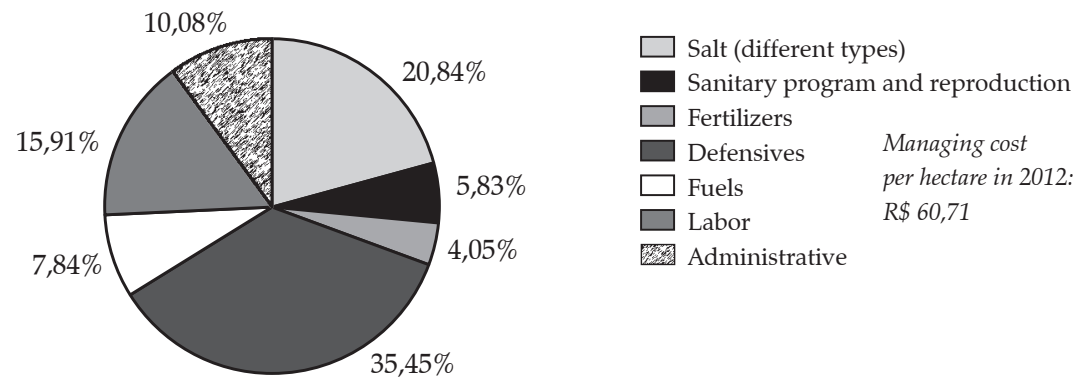

Source: Research results based on Agroconsult database. 
Figure 6. Cost structure for Complete Cycle with Growing technology

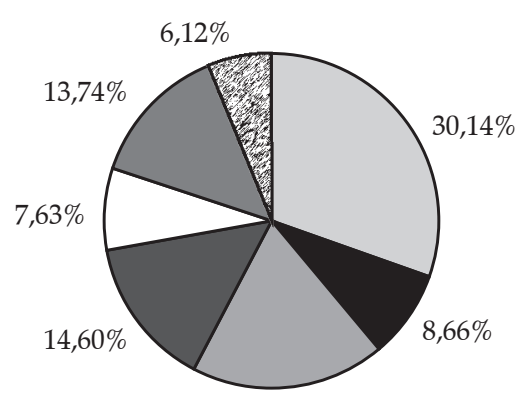

$19,10 \%$

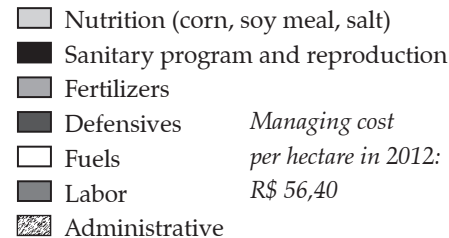

Administrative

Source: Research results based on Agroconsult database.

some parameters on productivity per ha ${ }^{10}$. The most common yield parameter used is stocking rate (number of animals per hectare), but, alone it does not capture the real productivity of pasture. The combination of production per ha (using slaughtered animals and carcass weight) and the number of animals in live weight is the productivity parameter used in order to map the technological profile. The average weight of cattle herd (which has different categories with different live weight) is 10.5 kilogram (average (a). So, the total production of live animal in CWE $(P H)$ in a given year was calculated as:

$$
P H_{t}=\left(T S_{t} \times S W_{t}\right) / 15+\left(C_{t}-C H_{t-1}\right) \times 10.5
$$

$\mathrm{PH}$ is the production of live animal in carcass weight equivalent (in @ CWE); TS is total slaughtered animals (in heads); $S W$ is the slaughter weight (in $\mathrm{Kg} /$ head, $\mathrm{CWE}$ ); $\mathrm{CH}$ is total cattle herd (in heads).

Dividing equation (1) by the total pasture area $(A p)$ will result on the productivity per hectare $(y l)$ in terms of live animal production in a given year in@CWE (or 15 kg CWE):

$$
y l_{t}=P H_{t} / A p_{t}
$$

10. Important to notice that BLUM has equations for cattle herd by cathegory (by animal age and sex), slaughter by cathegory, slaughter weight, calf production (animal birth), as described at Icone (2014). Those equations also show zoo technical indexes for beef and dairy sectors.
It is also important to use the productivity in terms of beef production per hectare $(\mathrm{kg} /$ ha), considering the total slaughtered animals multiplied by CWE and divided by pasture area.

The challenge on estimating beef production divided in different productivity levels is the lack of database, since all database available and estimated were exhausted. The next step is to estimate the share of production on each technological level.

For that purpose, this study used Agricultural Census database for 1996 and 2006 and estimated pasture area and cattle herd. First was estimated the starting point in 2006, using an optimization problem that gives the combination of technological levels that results on the average productivity calculated (equation (2)) and the assumptions on each technological level. It was used the "solver" analysis available at Excel software, which the objective function is the productivity equals to the number calculated (2) considering the range of each tech level and changing the shares of each tech so they sum $100 \%$. It is important to notice that "growing" tech can still be considered low for specialists, but considering the average yields estimated for Brazil and for the six regions, the share of yield that is higher than 6@/ha is rare in regions like Northeast Coast and Northeast Cerrado (Figures 7 and 8). 

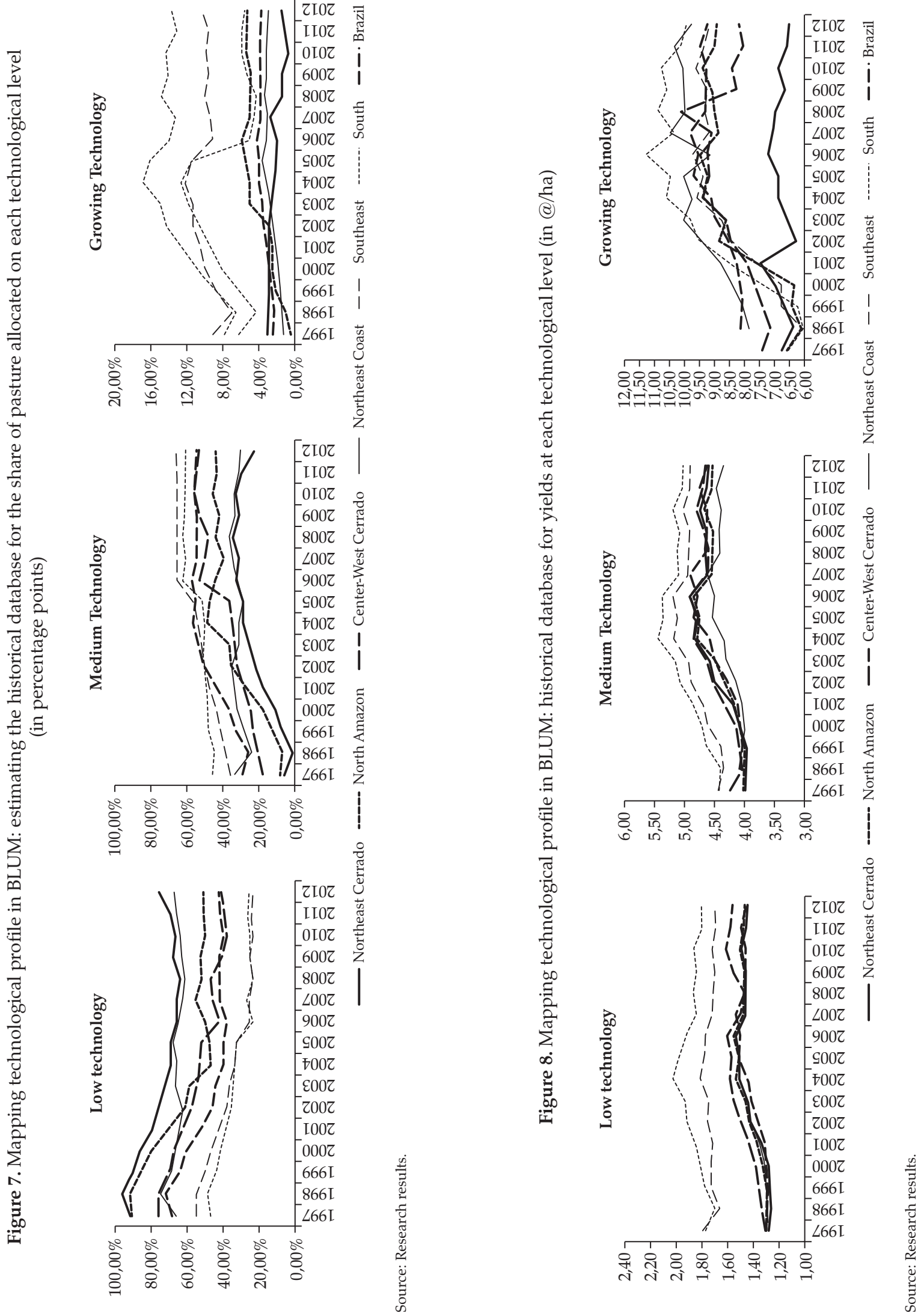
In addition, not only there was migration from one technology to another, but also was observed and estimated productivity changes for a given technology (Figure 8). Gradually, there was a reduction on low technology allocated area, increasing the range of medium and high productivity levels.

Between 1997 and 2006 there was a considerable change in the productivity profile of Brazilian beef sector in almost all regions, except in the Northeast Coast. The share of production using low tech reduced considerably and was largely displaced by medium tech. It is important to highlight the regions North Amazon and Northeast Cerrado, which reduced from 91\% the share of area in low tech to $52 \%$ and $68 \%$, respectively, showing that the occupation process in the frontier was followed by technological improvements. Growing tech has also increased in the South and Southeast regions, where there is high competition for land with other uses.

In the period from 2006 to 2012 the trend was similar, however, as there was a reduction of the total herd explained by the dynamics of the activity itself, the process on increasing productivity per hectare was slower. As market conditions changes, the intensification process also changes.

\section{Implementing beef sector technological profile in BLUM}

After estimating the database on technological profile, costs of production and returns per hectare for the beef sector by BLUM region, structural changes were implemented in the model in order to have endogenously estimated the three technological levels. The main idea is that each technological system compete for land with each other and also compete with other crops and native vegetation. That means that it was estimated a new set of competition matrices in order to be incorporated in BLUM, changing its land use dynamics.

In addition, the importance of beef and dairy sectors on affecting total land allocated to agricultural production was also changed. The assumption is that the displacement of natural vegetation by pastureland is determined by low technology system at time $t$, but it can improve technology on $t+1$ on the competition effect.

On BLUM land use section, the scale effect (total land allocated to agricultural use) is estimated considering the weighted average return of the agricultural sector, while the weighting vector of deforestation rate caused by each agricultural activity was obtained by satellite imagery and GIS modeling (see equation (4) at Icone, 2014). The return considered for each hectare of pasture over new agricultural frontier is determined by, first, low technology, and then competition for land can result on technological improvements of pastureland.

Cross area elasticity is represented by a set of competition elasticities matrices, one for each BLUM region, where competition effect among all crops and three technologies for pasture is considered (equation (9), Icone, 2014). In the case of competition between the three technological levels for the beef sector, cross elasticities are representing the change on the share of area for one technology as a response for the return of other technology. As an example, Table 2 compares the original elasticity matrix for the Center-West Cerrado region and the results incorporating the structural changes for beef and dairy sectors.

One might notice that the absolute value of the elasticities changed on the improved version compared to the previous one, mainly for pasture. The dynamics of pasture is the following: grains compete mainly with medium and growing technologies; sugarcane competes mainly with low technology pasture and competition among the three technologies of livestock goes from low to medium to growing. Also, since the matrix might comply with the regularity conditions (homogeneity, symmetry and adding up), the share of low technology level is determined as the result of total area allocated for agriculture less the share that goes to crops, medium and growing technology for livestock. The sum of the shares of all crops and pasture technologies needs to be one. 
Table 2. Comparing elasticities matrices for the Center-West Cerrado region: original version and implemented improvements on land use for pasture

\begin{tabular}{|c|c|c|c|c|c|c|c|c|c|}
\hline Previous version & $\begin{array}{c}\text { Corn } \\
\text { 1st crop }\end{array}$ & \multicolumn{2}{|c|}{ Soybeans } & Cotton & Rice & $\begin{array}{c}\text { Dry beans } \\
\text { 1st crop }\end{array}$ & \multicolumn{2}{|c|}{ Sugarcane } & Pasture \\
\hline Corn 1st crop & 0.1962 & \multicolumn{2}{|c|}{-0.2355} & -0.0452 & -0.0066 & -0.0014 & \multicolumn{2}{|c|}{-0.1426} & -0.0200 \\
\hline Soybeans & -0.0059 & \multicolumn{2}{|c|}{0.4674} & -0.0049 & -0.0021 & -0.0003 & \multicolumn{2}{|c|}{-0.0107} & -0.0543 \\
\hline Cotton & -0.0270 & \multicolumn{2}{|c|}{-0.1163} & 0.2532 & -0.0001 & 0.0000 & \multicolumn{2}{|c|}{-0.0397} & -0.0173 \\
\hline Rice & -0.0044 & \multicolumn{2}{|c|}{-0.0563} & -0.0001 & 0.1266 & 0.0000 & \multicolumn{2}{|c|}{-0.0120} & -0.0103 \\
\hline Dry beans 1st crop & -0.0022 & \multicolumn{2}{|c|}{-0.0189} & 0.0000 & 0.0000 & 0.1011 & \multicolumn{2}{|c|}{-0.0140} & -0.0005 \\
\hline Sugarcane & -0.0290 & \multicolumn{2}{|c|}{-0.0862} & -0.0135 & -0.0037 & -0.0017 & \multicolumn{2}{|c|}{0.5000} & -0.0625 \\
\hline Pasture & -0.0006 & \multicolumn{2}{|c|}{-0.0689} & -0.0009 & -0.0005 & 0.0000 & \multicolumn{2}{|c|}{-0.0128} & 0.0117 \\
\hline $\begin{array}{l}\text { Improved } \\
\text { Version }\end{array}$ & $\begin{array}{l}\text { Corn 1st } \\
\text { crop }\end{array}$ & Soybeans & Cotton & Rice & $\begin{array}{c}\text { Dry } \\
\text { beans } \\
\text { 1st }\end{array}$ & Sugarcane & $\begin{array}{l}\text { Pasture } \\
\text { Growing }\end{array}$ & $\begin{array}{l}\text { Pasture } \\
\text { Medium }\end{array}$ & $\begin{array}{c}\text { Pasture } \\
\text { Low }\end{array}$ \\
\hline Corn 1st crop & 0.1942 & -0.1855 & -0.0652 & -0.0066 & -0.0014 & -0.1026 & -0.0256 & -0.0085 & -0.0019 \\
\hline Soybeans & -0.0047 & 0.4619 & -0.0049 & -0.0021 & -0.0003 & -0.0107 & -0.0107 & -0.0107 & -0.0121 \\
\hline Cotton & -0.0389 & -0.1163 & 0.2532 & -0.0001 & 0.0000 & -0.0397 & -0.0066 & -0.0033 & -0.0015 \\
\hline Rice & -0.0044 & -0.0563 & -0.0001 & 0.1266 & 0.0000 & -0.0120 & -0.0020 & -0.0010 & -0.0031 \\
\hline Dry beans 1st crop & -0.0022 & -0.0189 & 0.0000 & 0.0000 & 0.1006 & -0.0060 & -0.0010 & -0.0005 & -0.0003 \\
\hline Sugarcane & -0.0159 & -0.0659 & -0.0103 & -0.0028 & -0.0006 & 0.5000 & -0.0010 & -0.0020 & -0.0269 \\
\hline Pasture Growing & -0.0028 & -0.0466 & -0.0012 & -0.0003 & -0.0001 & -0.0007 & 0.1000 & -0.0100 & -0.0010 \\
\hline Pasture Medium & -0.0012 & -0.0594 & -0.0008 & -0.0002 & 0.0000 & -0.0018 & -0.0128 & 0.1000 & -0.0720 \\
\hline Pasture Low & -0.0003 & -0.0823 & -0.0004 & -0.0008 & 0.0000 & -0.0296 & -0.0016 & -0.0879 & 0.0743 \\
\hline
\end{tabular}

Source: Research results.

\section{Dairy sector improvements}

Brazil was the fiftieth largest producer of fluid milk of the world in 2013 (USDA 2014), achieving 35.3 million tons of milk (IBGE, 2014c). The sector has been increasing production by $4 \%$ per year since 1995. Important drivers of this growth are the increase on consumer purchase power, social programs and improvements on the supply side (LINS, VILELA and GOMES, 2005).

For the purpose of analyzing land use dynamics, the dairy sector is important because it is an extensive land user in Brazil and as less land it uses, more feed it consumes. This means that dairy sector, together with beef sector, can be considered as an important land saver for Brazilian agricultural expansion as technological level is improved in the supply side.

The previous version of BLUM does not consider different systems of production for dairy sector. In order to better represent regional productivity patterns, it is important to consider the heterogeneities among the different technologies used. In addition, all dairy sector database needed to be revised, considering new information available.

The objective is to develop a new module for the dairy sector in BLUM, considering improvements on historical database for supply and demand side; estimate different technology profile per region; estimate demand equations and implement the improved module in BLUM.

\subsection{Historical database for dairy demand side}

The review of the demand database included data from PIA Produto - Pesquisa da Industria Anual (IBGE, 2014e), which informs the production and sales of industrialized products. This data was combined with other sources to compare and calculate net trade, fluid milk and industrial consumption, such as USDA (2014), IBGE (2014c), Secex (2014) and FNP (2014).

The industrial demand for dairy products was calculated using milk equivalent unit, combining weights to transform a final product 
in the amount of milk needed to produce one kilogram of product. The set of weighted index for 36 dairy products available in PIA (2014) is important because the information available in the supply side is total production of milk (IBGE, 2014c).

Although USDA (2014) presents balance sheets for the main dairy products and fluid milk, data is different from Brazilian official sources, such as exports and imports available at Secex (2014). For this reason, a mix of sources is needed. BLUM considers total net trade of dairy products, not separating several types of products as USDA (2014). It was preferred to simplify the analysis since data collection is not always available in Brazil for the demand side.

Using total production of milk (IBGE, 2014c), net trade and milk for industrial products, and also considering that final stocks variation is zero for a given year, we can calculate fluid milk consumption. Data shows that Brazil is currently a net importer of dairy products, in milk equivalent, although from 2004 to 2008 net trade was positive, as shown in Figure 9. Table 3 summarizes supply and demand historical balance sheet.

According to the results, despite the increase of fluid milk consumption in absolute value, industrialized dairy products have being increasing its share on final consumption in Brazil in the last ten years. This is an important fact to determine and estimate demand equations in BLUM. In addition, Brazil is still a net importer of dairy products, but improvements on the supply side (mainly on quality) can change this in the future (LINS, VILELA and GOMES, 2006).

\subsection{Historical database for dairy supply side}

As described before, informal beef production is an important issue in Brazil. For dairy, there are three official database for milk production: Pesquisa Trimestral do Leite (IBGE, 2014f), Pesquisa Pecuaria Municipal (IBGE, 2014c) and Agricultural Census (IBGE, 2014d). IBGE (2014f) has quarterly historical data of milk production by type of inspection at industrial level by State. IBGE (2014c) is a municipality survey for

Figure 9. Exports and imports (negative) for dairy products in milk equivalent (1,000 tons)

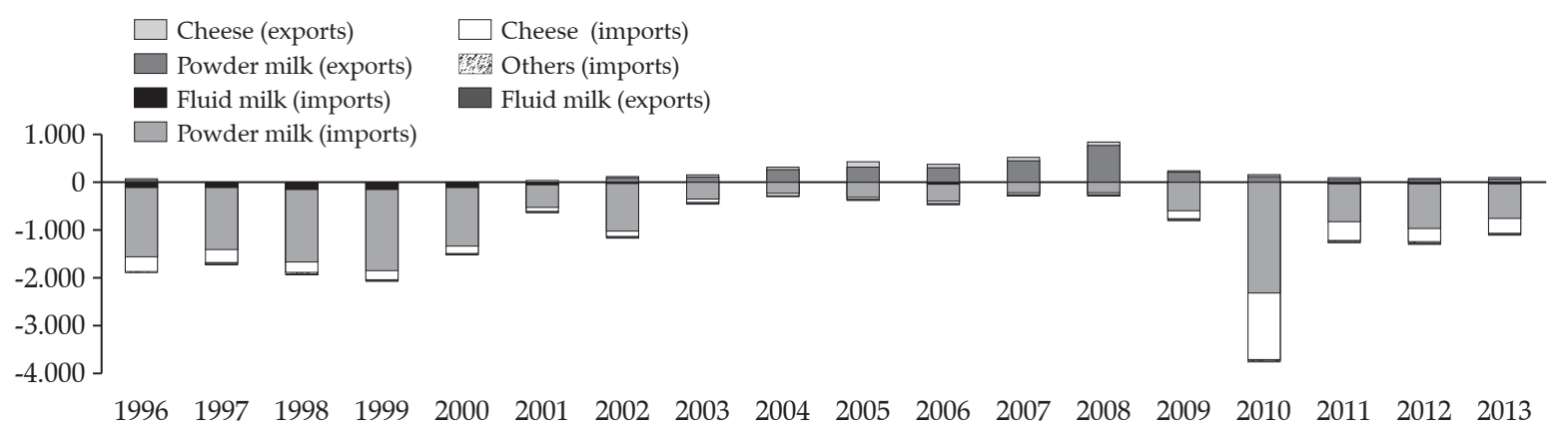

Source: Secex (2014) and research results.

Table 3. Supply and Demand Balance for Milk and Dairy in Brazil

\begin{tabular}{lccccccc}
\hline \multicolumn{1}{c}{$\mathbf{1 , 0 0 0}$ tons (milk equivalent) } & Source & $\mathbf{1 9 9 7}$ & $\mathbf{2 0 0 0}$ & $\mathbf{2 0 0 3}$ & $\mathbf{2 0 0 6}$ & $\mathbf{2 0 0 9}$ & $\mathbf{2 0 1 2}$ \\
\hline Production & IBGE & 19,220 & 20,354 & 22,915 & 26,153 & 29,949 & 33,264 \\
Industrial Demand & USDA, PIA & 12,503 & 13,155 & 13,817 & 16,580 & 19,252 & 22,549 \\
Fluid Milk Consumption & (calculated) & 8,383 & 8,643 & 9,303 & 9,541 & 11,159 & 11,843 \\
Net exports & SECEX & $-1,665$ & $-1,444$ & -206 & 31 & -461 & $-1,128$ \\
\hline
\end{tabular}

Source: Research results. 
milk production and dairy cows at farm level and provides historical data since 1974, and Agricultural Census survey (IBGE, 2014d) has detailed information at farm level for selected years.

According to Lins, Vilela and Gomes (2006), total production of milk can be considered the total sales of milk plus self-consumption in farms, while total sales can be separated into formal (inspected by federal, state or municipality regulatory agencies) and informal (not inspected).

Total production of milk and dairy cows considered was based on IBGE (2014c), since there is detailed historical data, and it captures total production of milk (both formal and informal). Figure 10 shows the difference between sources and that informal (not inspected) production has been decreasing overtime.
In addition total production, supply side in BLUM is regional and responds on profitabilities. For dairy, two important improvements were implemented: technological profile of milk production and costs structure and profitabilities for each technology by BLUM region.

\subsection{Estimating technological profile in BLUM}

Using IBGE (2014c), it is possible to have productivity per cow historical database per municipality per year. Since BLUM has six aggregated regions, it is possible to calculate the share of production by productivity range as a frequency distribution of the municipalities, considering that each municipality can be considered as a "representative farm", in average.

Figure 10. Milk production by source (in $\mathrm{kg}$ ) and informal production share (\%)

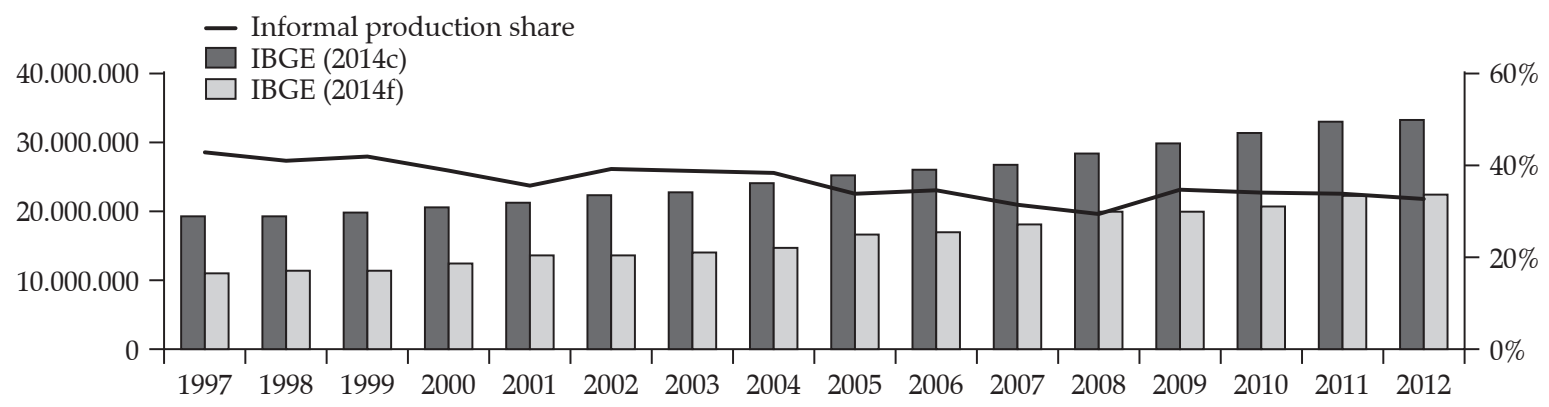

Source: IBGE $(2014 \mathrm{c}, \mathrm{f})$.

Figure 11. Results for productivity of milk per cow frequency using municipality survey in 2011
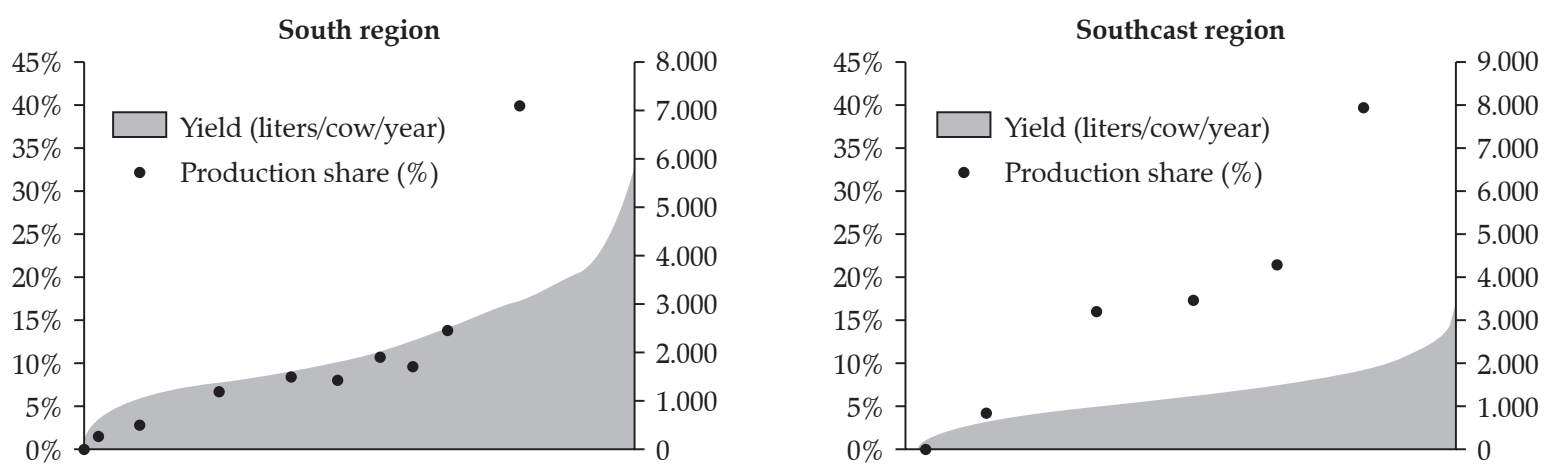

Source: IBGE (2014c) and research results. 
In order to implement productivity levels in BLUM and considering the calculated historical database, the range considered were:

a) Very low technology: from 0 to 4 liters per cow per day

b) Low technology: higher than 4 and up to 7 liters/cow/day

c) Medium technology: higher than 7 and up to 9 liters/cow/day

d) Growing technology: higher than 9 liters/ cow/day.

This division was based on the technological profile in each BLUM region from 1996 to 2013 (IBGE, 2014c), summarized in Table 4 for Brazil.

There were important migration from very low technology to low technology in almost all regions, except the South and Northeast Cerrado. In the South, migration occurred for higher levels of productivities, mainly for growing technology, confirming that the region has higher yields compared to other Brazilian regions. In the Northeast Cerrado, very low technology is still responsible for almost all milk production. North Amazon reduced the share of production on very low productivity from $98.8 \%$ in 1996 to $45.4 \%$ in 2013 , mostly migrating to low productivity levels.
Similar behavior was observed in the Center West Cerrado region. The Southeast region presented increase of production share on medium technology.

\subsection{Dairy costs of production}

For this study we used data from IBGE (2014c), CNA (2012) and Cepea (2012). In BLUM, all costs database are based upon operation variable costs, not considering depreciation, land opportunity costs and capital expenditure. Also, some costs were aggregated in order to be projected in BLUM based on macroeconomic indexes, fertilizers and transportation costs.

The share of each cost category differs among technologies and regions. Regional input prices such as feed are endogenously projected in BLUM, which affects cost level and share in each region. Feed costs considered in very low and low productivities' level were based upon mineral salt costs, while in higher technological levels supplementary feed as corn and soybean meal were included. For projections, we assume that all prices varies with corn and soybean meal, but absolute values and share of costs are different in each technology (Figure 12).

Table 4. Share of production at each productivity level for Brazilian average (in liters/cow/day)

\begin{tabular}{cccccccccc}
\hline & $\mathbf{1 9 9 6}$ & $\mathbf{2 0 0 0}$ & $\mathbf{2 0 0 4}$ & $\mathbf{2 0 0 8}$ & $\mathbf{2 0 1 0}$ & $\mathbf{2 0 1 1}$ & $\mathbf{2 0 1 2}$ & $\mathbf{2 0 1 3}$ \\
\hline $0-4$ & $57.2 \%$ & $59.8 \%$ & $54.5 \%$ & $46.0 \%$ & $42.5 \%$ & $41.0 \%$ & $38.7 \%$ & $33.8 \%$ \\
$4-7$ & $36.2 \%$ & $32.9 \%$ & $32.9 \%$ & $33.4 \%$ & $33.0 \%$ & $32.6 \%$ & $32.6 \%$ & $35.6 \%$ \\
$7-9$ & $4.0 \%$ & $4.6 \%$ & $8.5 \%$ & $11.5 \%$ & $12.3 \%$ & $13.1 \%$ & $13.6 \%$ & $15.1 \%$ \\
$>9$ & $2.6 \%$ & $2.7 \%$ & $4.2 \%$ & $9.1 \%$ & $12.2 \%$ & $13.3 \%$ & $15.1 \%$ & $15.5 \%$ \\
Brazil & $100.0 \%$ & $100.0 \%$ & $100.0 \%$ & $100.0 \%$ & $100.0 \%$ & $100.0 \%$ & $100.0 \%$ & $100.0 \%$ \\
\hline
\end{tabular}

Source: IBGE (2014c) and research results. 
Figure 12. Farm costs structure by technology level in South region in 2011
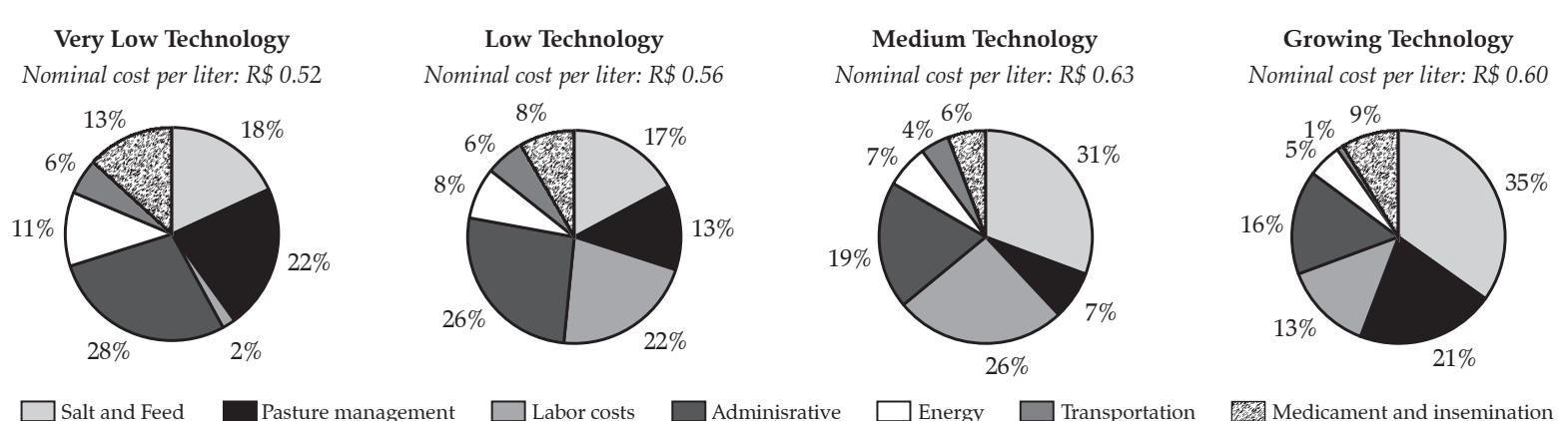

Source: Research results.

Operating revenue per liter of milk was calculated using regional prices and productivity per cow by technology. Operation revenue minus costs provides profitabilities per liter of milk.

Since one of the main characteristic of BLUM is its land use module, in addition to the analysis per liter of milk, it was estimated costs, revenue and profitabilities per hectare for dairy production. But the estimation of the dairy sector lacks a proper link between productivity (liters/ cow) and area used for the production. Currently, IBGE (2014c) has data for productivity (liters/cow), cows and production, but it does not have data for area allocated for dairy production because pasture area data is for beef and dairy production. Given that CNA (2012) dataset has area data and productivity (liters/cow), we estimate a relation between productivity measured by liters/cow and liters/hectare (Figure 13).
It was estimated the following function:

$$
Y h_{t}=252,29 e^{0,1715 Y_{t}}
$$

Where: $Y h=$ Productivity liters/hectare; $Y_{C}=$ Productivity liters/cow/day.

Since $Y_{c}$ is given in the IBGE dataset it is now possible to have $Y h$ for each municipality from Brazil. Also, it is possible to divide the production per municipality for $Y h$ that will give the area for milk production in each municipality.

We recognize that our sample is small and only capture few years and it was based on specific farms from survey, but this is the only dataset that has information about production, area, number of animals and cost available. Furthermore, several cattle raising farmers has beef as the main activity, but uses milking cows to produce and commercialize their products,

Figure 13. Productivities per cow and per hectare

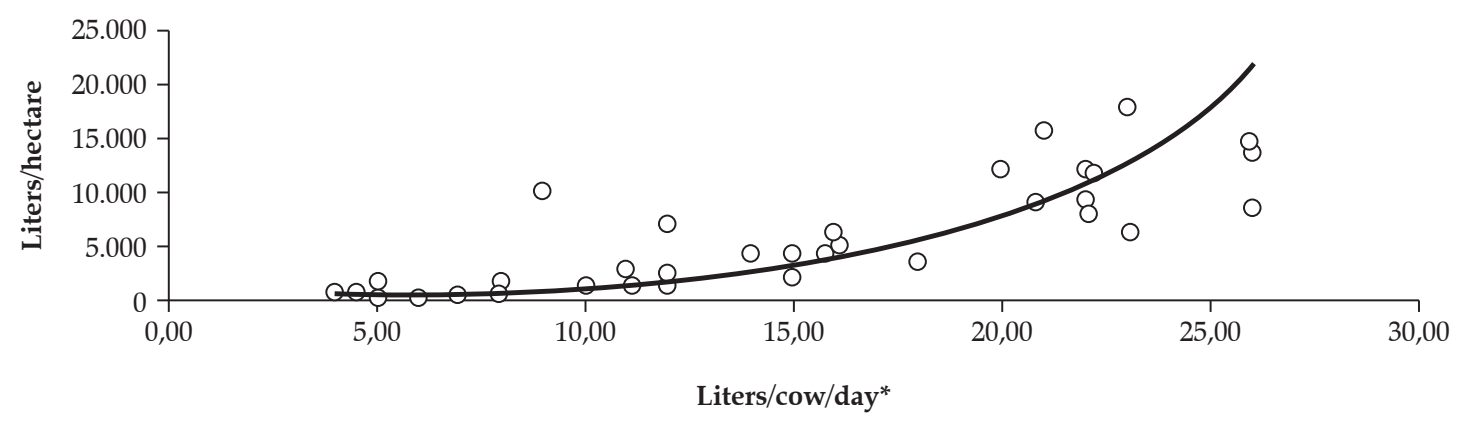

* Number of days considered was 365 .

Source: Research results. 
becoming impossible to measure exclusive land use for dairy sector.

With both considerations in mind, we calculated the above formula using the IBGE historical data and aggregated for BLUM regions in order to have the area used for productive dairy cows (Tables 5 and 6).

Those results are important to indicate the intensification process on dairy sector, regarding land use. From 2000 to 2012, total area increased $33 \%$ while the production of milk increased by $63 \%$. This result indicates important improvement on productivity in liters/hectare. Additionally, higher technological levels are increasing more rapidly than lower technologies.

Having productivity of milk per hectare in each region and technological level, it was also possible to calculate costs, revenues and profitabilities per hectare. Estimating equations for dairy module in BLUM.

\subsection{Demand side equations}

Total demand $\left(D T_{l, t}\right)$ for dairy products is formed by three components: domestic demand for fluid milk $\left(D_{l f, t}\right)$, domestic demand for manufactured milk $\left(D_{l m, t}\right)$ (milk and its sub- products, measured in milk equivalent) and net exports for milk and sub-products $\left(N T_{l, t}\right)$, measured in milk equivalent. In this way, the equations were estimated as follows:

$$
\begin{aligned}
& D T_{l t, t}=D_{l f, t}+D_{l m, t}+N T_{l t, t} \\
& D_{l f, t}=f\left(p_{l t, t}, Y_{c_{t}}, p o p\right) \\
& D_{l m, t}=f\left(p_{l m, t}, Y_{c_{t}} \text { trend }\right) \\
& N T_{l, t}=f\left(p_{l t, t} e_{t}^{*}, P R_{l t}\right)
\end{aligned}
$$

Where: $p_{l t}=$ domestic price of milk, $Y_{C}=$ GDP per capita in Brazil, pop Brazil's population, trend, $e^{*}$ $=$ real exchange rate, $P R_{l t}=$ total milk production.

Following the methodology adopted in BLUM demand side equations, ordinary least squares regressions were estimated. In the case that estimated regressions did not fit as expected, mainly because of the small number of observations, income-elasticities was based on Hoffmann (2010) and price-elasticities on Fapri (2014). A solver problem was used in order to minimize the sum of squared residuals and the elasticities were adapted for the observed data (Table 7).

Table 5. Production of milk per hectare in liters/hectare/year for Brazil (weighted average) by technology

\begin{tabular}{ccccccccc}
\hline Yield/cow & $\mathbf{1 9 9 6}$ & $\mathbf{2 0 0 0}$ & $\mathbf{2 0 0 4}$ & $\mathbf{2 0 0 8}$ & $\mathbf{2 0 1 0}$ & $\mathbf{2 0 1 1}$ & $\mathbf{2 0 1 2}$ \\
\hline $0-4$ & 386 & 384 & 384 & 382 & 383 & 385 & 384 \\
$4-7$ & 605 & 605 & 617 & 615 & 610 & 611 & 612 \\
$7-9$ & 963 & 971 & 963 & 969 & 977 & 997 & 976 \\
$>9$ & 1,993 & 1,810 & 1,538 & 1,798 & 1,723 & 1,775 & 1,730 \\
Average & 469 & 462 & 484 & 522 & 542 & 554 & 566 \\
\hline
\end{tabular}

Source: Research results.

Table 6. Estimated area used for milk production (1,000 hectares)

\begin{tabular}{cccccccc}
\hline Yield/cow & $\mathbf{1 9 9 6}$ & $\mathbf{2 0 0 0}$ & $\mathbf{2 0 0 4}$ & $\mathbf{2 0 0 8}$ & $\mathbf{2 0 1 0}$ & $\mathbf{2 0 1 1}$ & $\mathbf{2 0 1 2}$ \\
\hline $0-4$ & 27,408 & 30,791 & 33,276 & 33,173 & 34,025 & 34,181 & 32,502 \\
$4-7$ & 11,075 & 10,756 & 12,520 & 14,977 & 16,607 & 17,141 & 17,238 \\
$7-9$ & 774 & 946 & 2,060 & 3,289 & 3,874 & 4,208 & 4,501 \\
$>9$ & 243 & 293 & 640 & 1,396 & 2,181 & 2,407 & 2,820 \\
Total & 39,500 & 42,786 & 48,496 & 52,835 & 56,686 & 57,937 & 57,060 \\
\hline
\end{tabular}

Source: Research results. 
Table 7. Elasticities for milk and dairy domestic demand

\begin{tabular}{|c|c|c|c|c|c|}
\hline & \multirow{2}{*}{ FAPRI (2014) } & \multicolumn{2}{|c|}{ Income elasticity } & \multicolumn{2}{|c|}{ Own-price elasticity } \\
\hline & & Hoffmann (2010) & BLUM & FAPRI (2014) & BLUM \\
\hline Butter & 0.05 & 0.661 & & -0.06 & \\
\hline Cheese & 0.36 & 0.853 & & -0.21 & \\
\hline Fluid Milk & 0.44 & 0.393 & 0.375 & -0.20 & -0.282 \\
\hline Nonfat Dry Milk & 0.39 & 0.108 & & -0.21 & \\
\hline Whole Milk Powder & 0.39 & 0.108 & & -0.48 & \\
\hline Dairy Manufactured Products & & & 0.617 & & -0.334 \\
\hline
\end{tabular}

Source: Fapri (2014), Hoffmann (2010), research results.

Net trade (exports minus imports, in quantities) composes the last equation in dairy demand side. Several equations were estimated considering dairy products separately and aggregated net trade, so the best fitted one could be chosen. Explanatory variables were domestic price of milk, exchange rate and milk production. The last one is important since higher levels of production can increase net trade. In equilibrium, net trade price-elasticity curve can be calculated considering:

$$
\begin{aligned}
& N T=S-D \\
& \varepsilon_{N T}^{p}=\frac{1}{N T}\left(\varepsilon_{S}^{p} * S-\varepsilon_{D}^{p} * D\right)
\end{aligned}
$$

Where: $N T=$ dairy net exports (net trade); $S=$ supply of dairy products; $D=$ demand of dairy products; $\varepsilon^{p}=$ own price-elasticity for each variable.

From equation (9), calculated average net trade price elasticity was -4.49 , used in BLUM.

\subsection{Estimating supply side equations}

The mostimportantimprovementon modeling milk and dairy supply was implementing four technologies of production in BLUM: very low, low, medium and growing technologies. One might notice that, despite demand side is modeled at national level, the supply side is considered by BLUM region.

After calculating costs of production by technology level, as explained before, it is necessary to estimate the following equations for each BLUM region: yield per cow at each technological level; total milk cows; share of milk cows in each technological level; and total milk production. Aggregate Brazilian milk production is given by the sum of regional production, estimated as:

$$
\begin{aligned}
& Y_{l t, t}=\sum_{r=1}^{6} Y_{l t, r, t} \\
& Y_{l t, r, t}=\operatorname{MCows}_{r, t} * \text { Myield }_{r, t} \\
& \operatorname{Mcows}_{r, t}=f_{r}\left(\operatorname{Mcows}_{r, t-1}, p_{l t, r, t}, \operatorname{Cost}_{r, t}\right) \\
& \text { Myield }_{r, i, t}=f_{r}\left(\text { Myield }_{r, i, t-1}, \text { trend }\right) \\
& \operatorname{SMcows}_{r, i, t}=f_{r}\left(\begin{array}{l}
p_{l t, r, t}, \text { Myield }_{r, i, t} \text { Myield }_{r, j, t} \\
\text { Cost }_{r, i, t}, \operatorname{Cost}_{r, j, t}, \text { SMcows }_{r, i, t-1}
\end{array}\right) \\
& \operatorname{SMcows}_{t}=\sum_{r=1}^{6} \sum_{i=1}^{4} \operatorname{SMcows}_{r, i, t}=1
\end{aligned}
$$

In which: $r=$ BLUM region; Mcows = number of milk cows on farms, Myield $_{r, I, t}=$ yield per cow at technological level I; SMcows $s_{r, I, t}=$ share of regional milk cows at technology $i$; SMcows $=$ share of milk cows; Cost $_{r, I, t}$ is the cost per liter or $\mathrm{kg}$ of milk at technology $i$; $\operatorname{Cost}_{r j, t}$ is the cost per liter or $\mathrm{kg}$ of milk at technology $j$; Cost $_{r, t}=$ average cost per liter of milk (weighted average of technologies' cost).

In equation (14), share of milk cows by technology depends on farm revenue and costs of the own technology (i) and revenue and costs of a competition technology $(j)$, usually a higher level technology. 
Equation (12) was estimated using Ordinary Least Squares method for each region and technology level. For equations (13) and (14) were used Polled time-series estimations (or Panel analysis) in order to capture regional characteristics (considered as time-series cross-sections data). Pooled time-series and panel analysis were chosen due to increase on number of observations (from 16 to 96) and also to the possibility of differentiating regional characteristics (WOOLDRIDGE, 2002). It was tested (corrected and re-estimated for each case) for fixed effects, random effects (Hausman test), heteroskedasticity and crosssection contemporaneous correlation (Seemingly Unrelated Regressions - SUR).

Equation (14) was estimated for all technological levels, except for very low technology, since the sum of shares might be one in each year and region, as described at Equation (15). The share of milk cows at low technology in each region was considered as the result of $100 \%$ less the sum of all other technological levels share. Table 8 summarizes the results for supply elasticities for fluid milk production.

Using the share of milk cows per technology, it is possible to calculate total production of milk from Equation (11) using the weighted average yield (liters per cow for each technology multiplied by its estimated share) multiplied by total milk cows in each region, estimated in Equation (12). For each projected year in BLUM, equilibrium is achieved when national milk supply (Equation (10)) is equal national demand for dairy products (in milk equivalent at Equation (4)).

\section{Comparing results using BLUM previous and updated versions}

In order to compare different BLUM versions, the same scenario was simulated for 2030. "Previous" version (described at Icone, 2014) considers land use section and beef and dairy sectors without incorporating different technologies, while "Updated" version uses the improvements described in this paper. For the simulation, database on both versions were updated until 2013/2014 harvest seasons for all crops, beef and dairy products and parameters differs only on the improved modules. Macroeconomic scenario and assumptions were also aligned in both versions, so the different effects between both versions can be isolated and compared.

\subsection{Supply and demand}

Results for supply and demand for crops and industrial products are presented in Table 9. Production of grains, oilseeds and soybean meal in the updated version is higher than the previous BLUM version in 2030. The main reason is that implementing different technological levels on beef and dairy sectors better captured feed consumption (corn and soybean meal). As a consequence, soybean oil also increased in the updated version, due to its link with soybean meal (soybean crush industry).

In addition, production level for protein as whole increased in the updated version compared to the previous one. Separating beef

Table 8. Return supply elasticities for share of milk cows per tech - example for South region*

\begin{tabular}{lccc}
\hline & $\begin{array}{c}\text { Share of milk cows at } \\
\text { low tech }\end{array}$ & $\begin{array}{c}\text { Share of milk cows at } \\
\text { medium tech }\end{array}$ & $\begin{array}{c}\text { Share of milk cows at } \\
\text { growing tech }\end{array}$ \\
\hline Low tech profitability & 0.114 & & -0.458 \\
Medium tech profitability & -0.139 & 0.198 & 0.468 \\
Growing tech profitability & & -0.212 & \\
\hline
\end{tabular}

*Estimates also included other explanatory variables, such as lagged share of milk cows (Equation (14)).

Source: Research results. 
and dairy into different technologies improved the connection among grain and beef and dairy sectors, in supply, demand and prices. As higher technological levels are used, more feed consumption is needed.

Other products, as sugar and ethanol, presented a slightly different supply and demand balance comparing the results from both BLUM versions in 2030. This difference can be explained due to changes on equilibrium prices between the two models and, as a result, on supply and demand balance for all products. Changes on competition elasticities matrices allocating area for each crop considering competition among three technological levels for pasture and crops also explains those differences.

Specifically for dairy, since historical data has changed between versions in terms of splitting the demand side into fluid milk and demand for manufactured products, supply and demand balance altered importantly in the updated version compared to previous BLUM version. Production in 2030 is more than 9\% higher in the updated version, while the demand distribution also changed, increasing the demand for manufactured products and decreasing the demand for fluid milk. This change captures the tendency analyzed by Lima et al. (2006), who affirmed that Brazilian consumer profile is changing over time, increasing demand for higher value added of dairy products, showed in parameters re-calibration.

\subsection{Land Use and livestock sector}

Simulating a baseline using both BLUM previous version (no technologies in beef and dairy sectors) and updated version (implementing three technological levels for beef and four for dairy production), land use allocated to agricultural production is shown in Figure 14 .

Table 9. Supply and demand results for different versions of BLUM model (1,000 tons)

\begin{tabular}{|c|c|c|c|c|c|c|}
\hline Product & Variable & $\begin{array}{c}2010 \\
\text { (observed) }\end{array}$ & $\begin{array}{c}2013 \\
\text { (observed) }\end{array}$ & $\begin{array}{c}2030 \\
\text { Updated } \\
\end{array}$ & $\begin{array}{c}2030 \\
\text { Previous } \\
\end{array}$ & $\begin{array}{c}\text { Updated- } \\
\text { Previous (\%) }\end{array}$ \\
\hline \multirow{3}{*}{$\begin{array}{l}\text { Grains and } \\
\text { oilseeds }\end{array}$} & Production & 147,954 & 185,652 & 274,664 & 270,733 & $1.5 \%$ \\
\hline & Domestic Consumption & 113,124 & 120,091 & 166,947 & 165,150 & $1.1 \%$ \\
\hline & Net Trade & 35,092 & 63,528 & 107,469 & 105,347 & $2.0 \%$ \\
\hline \multirow{3}{*}{ Soybean Meal } & Production & 27,154 & 26,900 & 39,040 & 38,085 & $2.5 \%$ \\
\hline & Domestic Consumption & 12,944 & 14,000 & 19,965 & 19,096 & $4.5 \%$ \\
\hline & Net Trade & 13,629 & 13,329 & 19,076 & 18,989 & $0.5 \%$ \\
\hline \multirow{4}{*}{ Soybean Oil } & Production & 6,973 & 6,800 & 9,515 & 9,282 & $2.5 \%$ \\
\hline & Domestic Consumption & 5,187 & 5,397 & 7,479 & 7,440 & $0.5 \%$ \\
\hline & Biodiesel & 1,907 & 2,297 & 3,473 & 3,473 & $0.0 \%$ \\
\hline & Net Trade & 1,548 & 1,358 & 2,032 & 1,839 & $10.5 \%$ \\
\hline \multirow{3}{*}{ Sugar } & Production & 37,893 & 37,378 & 50,061 & 50,196 & $-0.3 \%$ \\
\hline & Domestic Consumption & 10,659 & 11,372 & 14,238 & 14,287 & $-0.3 \%$ \\
\hline & Net Trade & 27,514 & 26,700 & 35,808 & 35,901 & $-0.3 \%$ \\
\hline \multirow{3}{*}{$\begin{array}{l}\text { Ethanol } \\
\text { (million liters) }\end{array}$} & Production & 27,376 & 28,934 & 46,604 & 47,149 & $-1.2 \%$ \\
\hline & Domestic Consumption & 25,501 & 25,663 & 42,666 & 43,229 & $-1.3 \%$ \\
\hline & Net Trade & 1,828 & 1,905 & 3,911 & 3,907 & $0.1 \%$ \\
\hline \multirow{3}{*}{$\begin{array}{l}\text { Beef, broiler and } \\
\text { pork meats }\end{array}$} & Production & 24,833 & 25,925 & 35,003 & 34,861 & $0.4 \%$ \\
\hline & Domestic Consumption & 18,801 & 19,639 & 24,420 & 24,823 & $-1.6 \%$ \\
\hline & Net Trade & 6,031 & 6,328 & 10,584 & 10,038 & $5.4 \%$ \\
\hline \multirow{4}{*}{$\begin{array}{l}\text { Dairy } \\
\text { (in milk } \\
\text { equivalent) }\end{array}$} & Production & 31,628 & 35,273 & 50,987 & 46,711 & $9.2 \%$ \\
\hline & Fluid Consumption & 12,101 & 11,222 & 15,536 & 16,057 & $-3.2 \%$ \\
\hline & Industrial Consumption & 23,056 & 25,076 & 35,353 & 30,789 & $14.8 \%$ \\
\hline & Net Trade & $-3,534$ & $-1,005$ & 97 & -134 & $-172.7 \%$ \\
\hline
\end{tabular}

Source: Research results. 
Figure 14. Land use allocated to crops (first harvest), pasture and planted forest (1,000 ha)

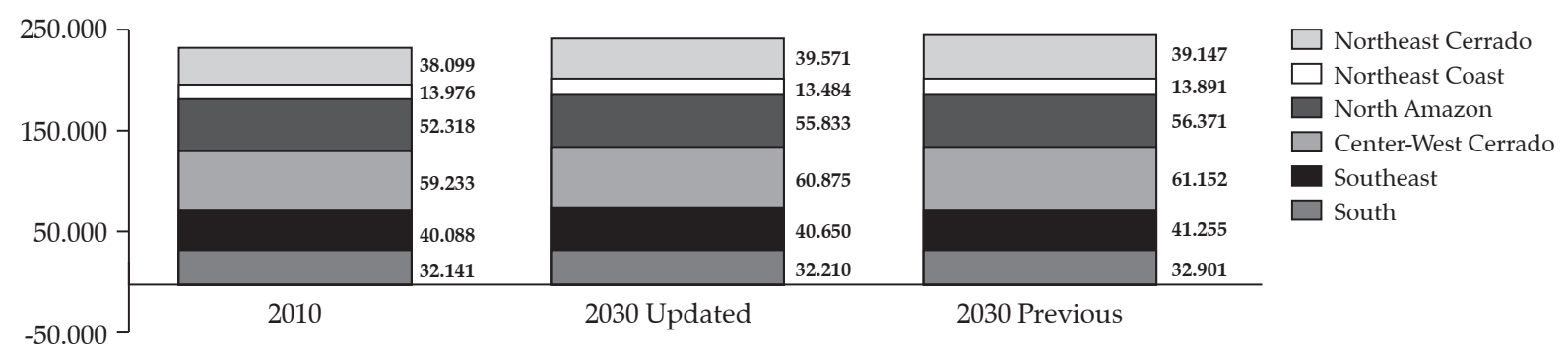

Source: Research results.

Results show that the absolute value of total land allocated for agriculture is lower in the updated version by 2 million hectares in 2030, compared to previous version, and also land allocation differs among regions. Expansion in the Cerrado might occur more significantly in the Northeast Cerrado region, while in the CenterWest Cerrado, pasture intensification and double cropping will be more important in 2030. Table 10 confirms that intensification process on beef and dairy sectors is increasing more rapidly compared to the previous version of the model. As a result, pastureland is lower and beef production is higher in the updated version in 2030, in average for Brazil, with a lower stock of cattle herd needed. For milk and dairy production, similar trend is presented in Table 11.

Introducing different technological levels in BLUM for the dairy sector changed the supply and demand equilibrium into a higher level compared to the previous version of the model in 2030. Mainly, updated version captures market

Table 10. Pasture area by technology (updated version) and total for Brazil

\begin{tabular}{|c|c|c|c|}
\hline Technology/Total & 2010 & 2030 (updated) & 2030 (previous) \\
\hline Low Tech & 81,298 & 79,256 & NA \\
\hline Medium Tech & 90,439 & 82,363 & NA \\
\hline Growing Tech & 10,925 & 13,590 & NA \\
\hline Total pasture area (1,000 ha) & 182,661 & 175,209 & 178,803 \\
\hline Total Beef Production (1,000 tons) & 9,365 & 13,172 & 12,804 \\
\hline Cattle herd (1,000 heads) & 209,541 & 226,730 & 233,747 \\
\hline
\end{tabular}

NA: not available.

Source: Research results.

Table 11. Milk production by technology (updated version) and total for Brazil

\begin{tabular}{lccc}
\hline \multicolumn{1}{c}{ Yield } & $\mathbf{2 0 1 0}$ & $\mathbf{2 0 3 0}$ (updated) & 2030 (previous) \\
\hline Very Low (0-4 liters/cow/day) & $13,427,933$ & $13,066,043$ & NA \\
Low (4-7) & $10,433,010$ & $16,377,936$ & NA \\
Medium (7-9) & $3,897,711$ & $9,477,967$ & NA \\
Growing (>9 liters/cow/day) & $3,869,117$ & $12,064,622$ & NA \\
Total milk production (tons) & $31,627,771$ & $50,986,568$ & $46,710,907$ \\
Total dairy cows (heads) & $22,924,914$ & $26,977,059$ & $26,890,906$ \\
Average liters/cow/day & 3.67 & 5.03 & 4.62 \\
\hline
\end{tabular}

NA: not available.

Source: Research results. 
dynamics that drives technological improvements on dairy sector and the model is now capable of allocating milk production into different technological levels for each BLUM region, not considering only the average technology as in the previous version. This fact explains the change on production level, considering that the number of total dairy cows did not change significantly in both version.

In addition, as observed on historical data dynamics, distribution of production in each technology differs from 2010, increasing the share of medium and growing technology and reducing the share of milk production using very low technology.

\section{Final considerations}

Brazil is an important player on agricultural sector and land use change is an important driver for GHG emissions and environmental concerns in the country. Several models try to capture and implement cause-effect analysis on land use change, both locally and globally.

The Brazilian Land Use Model - BLUM, has being used to measure land use change and agricultural supply and demand for Brazil, using empirical evidence together with literature review in order to calibrate the main drivers of land use change.

In this paper, modeling beef and dairy sectors was completely revised, incorporating new database and improving land use change analysis capturing drivers for the intensification process and for productivities' improvements for Brazil. This analysis contributes to the literature not only because it implemented new modules in BLUM and improved modeling land use change, but also because it brought new evidences into discussion.

First, in order to estimate supply and demand for beef and dairy for Brazil, considering only "average" technological level of production, such as the previous BLUM version, does not capture different behavior in terms of introducing new productivity improvements. Agents using very low technology respond differently (in terms of profitability response) compared to the ones that use higher technological levels. Also, competition with crops is also a key issue to be considered, since very low technologies can change land use (into a different activity) more rapidly than higher productivity levels. As a result, not separating different technologies can over estimate land allocated for agriculture.

Second, historical data for beef and dairy sectors shows that Brazil has being improving technological level of production over time, mainly measured by production per hectare or per head of cattle. Historical database analysis show that occupation process in the frontier (North Amazon and Center-West Cerrado) used low technology first, but improved technologies in the following years. This conclusion is also aligned with Martha Jr. et al. (2011) and Strassburg et al. (2014).

Third, considering the baseline scenarios simulated on both updated and previous BLUM versions, it is important to notice that although supply and demand equilibrium did not change much between the two versions, results for land use changed importantly. For similar levels of agricultural production, pastureland was $2 \%$ lower than in the previous version (or 3.5 million hectares), showing different behavior on intensification process after separating productivities' levels in the model. The need for additional land for agriculture reduced by 2 million hectares in 2030, comparing both versions. Again, modeling land use change is key for measuring GHG emissions in Brazil for agriculture and Land Use, Land Use Change and Forestry sectors.

Finally, as economic agents behavior changes along time, and considering that new laws, approaches and database are available for research and analysis, it is important to constantly (or as much as possible) revise the assumptions and improve modeling land use change. Also, bringing empirical evidences into modeling is key for land use change impact analysis, as shown in this paper and as pointed out by Nassar et al. (2011). 


\section{References}

ABIEC -Brazilian Beef Exporters Association. Brazilian Livestock Profile. Annual report 2015. Apex Brasil, 2015. Available at: www.abiec.com.br

AGROCONSULT. Base de dados da divisão pecuária. Florianópolis-SC. 2013. (personal contact).

ANTONIALLI, L. M. and GALAN, V. B. Evolução Tecnológica e Competitividade de uma Pequena Empresa Rural que atua na Pecuária Leiteira. Cad. Adm. Rural, Lavras, v. 9, n. 1, jan./jun. 1997. Available at: $\quad<$ http://200.131.250.22/revistadae/index.php/ora/ article/viewFile/129/126>.

ARRUDA, Z. J. A Bovinocultura de Corte no Brasil e Perspectivas para o setor. Campo Grande, Embrapa Empresa Brasileira de Pesquisa Agropecuária, 1994. Available at: < http://www.infoteca.cnptia.embrapa.br/ infoteca/handle/doc/316639>.

CEPEA - Centro de Estudos Avançados em Economia Aplicada - ESALQ/USP. 2012. Custos de produção. Available: $\quad<$ http://cepea.esalq.usp.br/boi/?page $=372$ and http://cepea.esalq.usp.br/leite/?page $=672>$.

CNA - Confederação Nacional da Agricultura. 2012. Custos de produção da pecuária de corte e de leite. Available at: <http://www.canaldoprodutor. com.br/sobre-sistema-cna/projetos-e-programas/ programa-campo-futuro/apresentacao $>$.

$\mathrm{COHN}$, A. S. et al. Cattle ranching intensification in Brazil can reduce global greenhouse gas emissions by sparing land from deforestation. PNAS, mar. 2014. (doi:10.1073/pnas. 1307163111).

GIBBS, H. K. et al. Did Ranchers and Slaughterhouses Respond to Zero-Deforestation Agreements in the Brazilian Amazon? Conservation Letters, 16 mar. 2015.

GOUVELLO, C. de, SOARES-FILHO, B. and NASSAR, A. (Coord.). Estudo de Baixo Carbono para o Brasil: Uso da Terra,MudançasdoUsoda TerraeFlorestas. Washington, The World Bank, Energy Sector Management Assistance Program, 2010. Available at: <http:// siteresources.worldbank.org/BRAZILINPOREXTN/ Resources/3817166-1276778791019/UsoTerra_Final_ Portugue.pdf $>$

FNP - Informa Economics. Anualpec - Anuário da Pecuária Brasileira. São Paulo, FNP, 2014.

IBGE - Instituto Brasileiro de Geografia e Estatística. 2014a.PesquisaTrimestraldoAbatedeAnimais. Database available at: $<$ http://www.sidra.ibge.gov.br/bda/tabela/ listabl.asp? $\mathrm{z}=\mathrm{t} \& \mathrm{o}=1 \& \mathrm{i}=\mathrm{P} \& \mathrm{c}=1092 \#$ nota $>$.
. 2014b. Pesquisa Trimestral do Couro. Database available at: <http://www.sidra.ibge.gov.br/bda/tabela/ listabl.asp? $\mathrm{z}=\mathrm{t} \& \mathrm{o}=1 \& \mathrm{i}=\mathrm{P} \& \mathrm{c}=1089>$.

. 2014c. Pesquisa Pecuária Municipal. Database available at: <http://www.sidra.ibge.gov.br/bda/tabela/ listabl.asp? $c=73 \& z=p \& o=26>$.

.2014d. Censo Agropecuário. Database available at: <http://www.sidra.ibge.gov.br/bda/acervo/acervo2. $\mathrm{asp} ? \mathrm{e}=\mathrm{v} \& \mathrm{p}=\mathrm{CA} \& \mathrm{z}=\mathrm{t} \& \mathrm{o}=24>$.

2014e. Pesquisa Industrial Anual - Produto. Database available at: <http://www.sidra.ibge.gov.br/ bda/tabela/listabl.asp?c $=3463 \& z=p \& o=18>$.

. 2014f. Pesquisa Trimestral do Leite. Database available at: <http://www.sidra.ibge.gov.br/bda/ default.asp? $\mathrm{z}=\mathrm{t} \& \mathrm{o}=1 \& \mathrm{i}=\mathrm{P}>$.

ICONE - Institute for International Trade Negotiations. 2014. The Brazilian Land Use Model BLUM. Available at: < http://www.iconebrasil.com.br/ datafiles/publicacoes/estudos/2012/descricao_blum _ the_brazilian_land_use_model_blum_0106.pdf > .

IEA - Instituto de Economia Agrícola. 2010. Database available at: <http://www.iea.sp.gov.br/out/ bancodedados.html>

LAPIG - Laboratório de Processamento de Imagens e Geoprocessamento. 2014. Radiografia das Pastagens no Brasil. Goiânia, LAPIG, dez. 2014. Available at: <http:/issuu.com/sae.pr/docs/ estudo_radiografia_das_pastagens $>$.

LIMA, M. S. et al. Innovation of functional products in the brazilian dairy industry: case study of Elegê Alimentos S. A. In: International Conference on Management of Technology (15: 2006: Beijing). East meets west: challenges and opportunities in the Era of Globalization. Beijing: IAMOT, 2006. Available at: $<$ http://hdl.handle.net/10183/597>.

LINS, P. M. G., VILELA, P. S. and GOMES, S. T. Diagnóstico da Pecuária Leiteira do Estado de Minas Gerais em 2005: relatório de pesquisa. Belo Horizonte, FAEMG, 2006. 156p.

MARTHA JR., G., ALVES, E. and CONTINI, E. Pecuária Brasileira e a Economia de Recursos Naturais. Brasilia-DF, Embrapa, maio 2011, n. 1. Available at: <http:// www.infoteca.cnptia.embrapa.br/infoteca/handle/ doc/908616>.

NASSAR, A. M. et al. Biofuels and land-use changes: searching for the top model. Interface Focus, 2011a. (doi:10.1098/rsfs.2010.0043).

NEPSTAD, D. et al. Slowing Amazon deforestation through public policy and interventions in beef and 
soy supply chains. Science, Special Edition, v. 344.6 jun. 2014. ISSUE 6188.SECEX - AliceWeb. 2014. Estatística do Comércio Exterior Brasileiro. Available at: <http:// aliceweb.mdic.gov.br/>.

STEHFEST, E. et al. Options to reduce the environmental effects of livestock production - comparison of two economic models. Agricultural Systems, v. 114, 2013, p. 38-53. (http://dx.doi.org/10.1016/j.agsy.2012.07.002)

STRASSBURG, B. N. et al. When enough should be enough: Improving the use of current agricultural lands could meet production demands and spare natural habitats in Brazil. Global Environmental Change, v. 28,2014, p. $84-97$.

USDA - United States Department of Agriculture. 2014. Foreign Agricultural Services: Production, Supply, Distribution. Database available at: $<$ http://apps.fas. usda.gov/psdonline/psdHome.aspx $>$.

WOOLDRIDGE, J. M. Econometric Analysis of Cross Section and Panel Data. Cambridge: The MIT Press, 2002. $737 \mathrm{p}$. 
